\title{
Detection of Leishmania infantum in naturally infected Lutzomyia longipalpis (Diptera: Psychodidae: Phlebotominae) and Canis familiaris in Misiones, Argentina: the first report of a PCR-RFLP and sequencing-based confirmation assay
}

\author{
Soraya Alejandra Acardi ${ }^{1 /+}$, Domingo Javier Liotta ${ }^{1}$, María Soledad Santini ${ }^{2}$, \\ Carlo Mariano Romagosa ${ }^{3}$, Oscar Daniel Salomón² \\ ${ }^{1}$ Laboratorio de Biología Molecular Aplicada, Facultad de Ciencias Exactas, Químicas y Naturales, Universidad Nacional de Misiones, \\ Posadas, Misiones, Argentina ${ }^{2}$ Centro Nacional de Diagnóstico e Investigación en Endemo-epidemias, \\ Administración Nacional de Laboratorios e Institutos de Salud, Ministerio de Salud de la Nación, Buenos Aires, Argentina \\ ${ }^{3}$ Instituto Municipal de Sanidad Animal, Secretaria de Calidad de Vida, Posadas, Misiones, Argentina
}

In this study, a genotypification of Leishmania was performed using polimerase chain reaction-restriction fragment length polymorfism (PCR-RFLP) and sequencing techniques to identify species of Leishmania parasites in phlebotomine sand flies and dogs naturally infected. Between January-February of 2009, CDC light traps were used to collect insect samples from 13 capture sites in the municipality of Posadas, which is located in the province of Misiones of Argentina. Sand flies identified as Lutzomyia longipalpis were grouped into 28 separate pools for molecular biological analysis. Canine samples were taken from lymph node aspirates of two symptomatic stray animals that had been positively diagnosed with canine visceral leishmaniasis. One vector pool of 10 sand flies (1 out of the 28 pools tested) and both of the canine samples tested positively for Leishmania infantum by PCR and RFLP analysis. PCR products were confirmed by sequencing and showed a maximum identity with L. infantum. Given that infection was detected in one out of the 28 pools and that at least one infected insect was infected, it was possible to infer an infection rate at least of $0.47 \%$ for $\mathrm{Lu}$. longipalpis among the analyzed samples. These results contribute to incriminate $\mathrm{Lu}$. longipalpis as the vector of $\mathrm{L}$. infantum in the municipality of Posadas, where cases of the disease in humans and dogs have been reported since 2005.

Key words: visceral leishmaniasis - Leishmania infantum - Lutzomyia longipalpis - Argentina

Visceral leishmaniasis (VL) is the most severe clinical manifestation of leishmaniasis observed worldwide, with an estimated incidence of roughly 500,000 cases per year and a mortality rate of 59,000 deaths per year. The primary parasite, vector and reservoir involved in the transmission cycle in Latin America have been identified as Leishmania infantum, Lutzomyia longipalpis and Canis familiaris (PAHO 2008), respectively.

The presence of Lu. longipalpis has been reported in northeastern Argentina (specifically the cities of Candelaria and Corpus, in the province of Misiones) since the 1950s (Salomon et al. 2001). However, it was not until the urban VL outbreaks of 2006 in the state of Mato Grosso do Sul (MS), Brazil, and the city of Asunción, Paraguay, that the first human case of VL was reported in Posadas, a city in the province of Misiones, Argentina. Investigations prompted by this case led to the discovery of Lu. longipalpis in the backyard of the home of the infected individual; this was followed by diagnosis of the disease in several dogs from the same neighborhood. The human case was confirmed by the presence of

Financial support: CeNDIE, CONICET, LaBiMAp + Corresponding author: sorayacardi1@gmail.com Received 17 February 2010

Accepted 15 June 2010 parasites in bone marrow smears, as well as by culture, serology (rK39 dipstick) and PCR (Leishmania genus); furthermore, parasite isolations were performed in the canine confirmation procedure (Salomon et al. 2008). By December of 2009, 39 human VL cases had been reported in the urban area of Posadas, according to the National System Surveillance of Health database.

Apart from immunoserological evidence and amastigote observation in smears, there has been no confirmation of the specific parasite species involved in this outbreak, the southernmost focus of VL known. Therefore, in this study we performed a Leishmania genotypification in phlebotomine sand flies and dogs using polimerase chain reaction-restriction fragment length polymorfism (PCR-RFLP) and sequencing techniques (Aransay et al. 2000, Jorquera et al. 2005, de Pita-Pereira et al. 2005, 2008). The primary goal of this work was to detect and identify the Leishmania species present and to identify putative vectors and reservoirs of these parasites in this focus; such information could lead to a better understanding of the local disease epidemiology and how it relates to the nearby northern VL foci.

\section{SUBJECTS, MATERIALS AND METHODS}

Sand fly and animal samples - Phlebotomine sand flies were captured with CDC minilight traps that were operated overnight. The traps were located at 13 peri- 


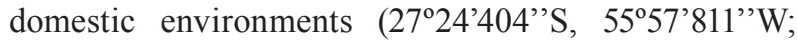
$27^{\circ} 24^{\prime} 045^{\prime}$ 'S , 55 56'884' 'W; 27²3'001' 'S, 55 56 '667' 'W; $27^{\circ} 24^{\prime} 030^{\prime \prime} \mathrm{S}, 55^{\circ} 55^{\prime} 342^{\prime \prime} \mathrm{W}$; $27^{\circ} 24^{\prime} 471^{\prime \prime} \mathrm{S}, 55^{\circ} 55,337^{\prime \prime} \mathrm{W}$; $27^{\circ} 23^{\prime} 333^{\prime \prime} \mathrm{S}, 5^{\circ} 55^{\prime} 462^{\prime \prime} \mathrm{W} ; 2^{\circ} 22^{\prime} 431^{\prime \prime} \mathrm{S}, 5^{\circ} 56^{\prime} 648^{\prime \prime} \mathrm{W}$;

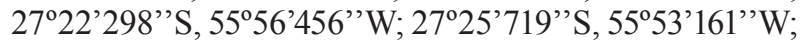
$27^{\circ} 25^{\prime} 754^{\prime \prime} \mathrm{S}, 5^{\circ} 53^{\prime} 210^{\prime \prime} \mathrm{W} ; 7^{\circ} 23^{\prime} 012^{\prime \prime} \mathrm{S}, 55^{\circ} 56^{\prime} 724^{\prime \prime} \mathrm{W}$; $27^{\circ} 23^{\prime} 855^{\prime \prime} \mathrm{S}, 55^{\circ} 56^{\prime} 433^{\prime \prime} \mathrm{W} ; 27^{\circ} 22^{\prime} 737^{\prime}$ 'S , 55 56'431'’W) between 22 January-18 February within the city of Posa-

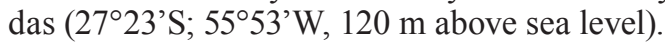

Taxonomic identification was performed according to Young and Duncan (1994), with the modification of Andrade Filho et al. (2003); Lu. longipalpis was the only species found. Random selection of sand flies from each trap was collected and stored at $-20^{\circ} \mathrm{C}$ for molecular analysis. Only traps that contained five or more females were included in the study. The females were assembled in groups (5-12 specimens per group) belonging to the same trap. The percentage of females used for PCR per trap ranged from $52-100 \%$ in 12 of the 13 traps, whereas in the remaining trap, $37 \%$ of the females were used.

Canine samples were collected by a medical veterinarian at the Posadas Municipality Animal Health Institute. Lymph node aspirates used for PCR analysis were collected from two symptomatic stray animals from Posadas that had been positively diagnosed with canine $\mathrm{VL}$; the positive diagnoses were confirmed either by rk39 dipstick or lymph node smear.

DNA extraction, PCR-RFLP and cycle sequencing - Sand flies were macerated with a sterile glass micromortar in $1.5 \mathrm{~mL}$ tubes containing $500 \mu \mathrm{L}$ lysis buffer (10 mM tris- $\mathrm{HCl}, \mathrm{pH} 8 ; 100 \mathrm{mM} \mathrm{NaCl} ; 0.45 \%$ Tween $20 ; 0.25 \%$ SDS; $200 \mu \mathrm{g} / \mathrm{sample}$ proteinase $\mathrm{K}$ ) and incubated at $58^{\circ} \mathrm{C}$ for $6 \mathrm{~h}$, followed by a purification step with an equal volume of a mixture of phenol/chloroform/ isoamilic alcohol (25:24:1 ratio, $\mathrm{pH}$ 8). Overnight DNA precipitation was performed with $100 \%$ ethanol and pellets were resuspended in $50 \mu \mathrm{L}$ DNAse/RNAse-free distilled water according to de Pita-Pereira et al. (2005) with some minor modifications.

Lymph node samples were processed with $500 \mu \mathrm{L}$ lysis buffer (10 mM tris- $\mathrm{HCl}, \mathrm{pH} 8 ; 100 \mathrm{mM} \mathrm{NaCl} ; 0.45 \%$ Tween 20; $0.25 \%$ SDS; $200 \mu \mathrm{g} /$ sample proteinase $\mathrm{K}$ ) and incubated at $58^{\circ} \mathrm{C}$ for $3 \mathrm{~h}$. DNA purification and precipitation steps were performed as previously described for phlebotomine samples.

The PCR assay was performed according to the protocol suggested by Marfurt et al. (2003); the described primers Fme (5'-TAT TGGTAT GCG AAA CTT CCG-3') and Rme (5'-ACA GAA ACT GAT ACT TAT ATA GCG-3') that target the mini-exon gene present as tandem repeats in all species of the Leishmania genus were used. The reaction was carried out with $5 \mu \mathrm{L}$ of each sample in a final volume of $50 \mu \mathrm{L}$ containing 1X PCR buffer $(200$ $\mathrm{mM}$ tris- $\mathrm{HCl}, \mathrm{pH} 8), 0.1 \mathrm{mM}$ EDTA, $1 \mathrm{mM}$ DTT, 50\% glycerol (v/v) (Invitrogen), $1 \mathrm{mM} \mathrm{MgCl}_{2}$ (Invitrogen), 10\% DMSO (Sigma), 0.2 mM dNTP Mix, $0.5 \mu \mathrm{M}$ Fme primer, $0.5 \mu \mathrm{M}$ Rme primer and $1.4 \mathrm{U}$ Taq polymerase (Invitrogen). Up to $10 \mu \mathrm{L}$ of the amplification product was analyzed by $2 \%$ agarose gel electrophoresis in TBE buffer containing ethidium bromide $(0.5 \mu \mathrm{g} / \mathrm{mL})$.
The RFLP assay was performed by digesting $10 \mu \mathrm{L}$ of the $418 \mathrm{bp}$ PCR product using the Eae I restriction enzyme (5'-Py $\boldsymbol{\nabla G G C C P u - 3 ' , ~ N e w ~ E n g l a n d ~ B i o l a b s ) . ~}$ The DNA fragments were resolved by $2.5 \%$ agarose gel electrophoresis in TBE buffer containing ethidium bromide $(0.5 \mu \mathrm{g} / \mathrm{mL})$.

Sequence confirmation of the $418 \mathrm{bp}$ product was performed by automatic cycle sequencing of both DNA chains using a fluorescent ddNTP terminator system (Macrogen Inc).

\section{RESULTS}

In this study, we performed PCR analysis on a selected sample of female Lu. longipalpis $(\mathrm{n}=211)$ grouped into 28 pools corresponding to 13 capture sites and two canine samples collected from symptomatic dogs. One vector pool of 10 sand flies (Genbank accession GU565337) and both of the symptomatic canine samples (Genbank accessions GU565338 and GU565339) tested positively for $L$. infantum by PCR and RFLP pattern analysis (Figure). A BLAST search performed against the Genbank database using the PCR product DNA sequences showed a maximum identity with L. infantum.

The detection limit of the assay, when performed with L. infantum isolated from local dogs, was determined to be 10 picograms. Assuming that the total DNA content of Leishmania is approximately 100 femtograms per genome (Myler \& Stuart 2000, Gontijo \& de Carvalho 2003), the positive pool analyzed in this study contained nearly 100 parasites.

Although the sand fly sample is not representative of the total population of sand flies in Posadas, we found a $3.5 \%$ rate of $L$. infantum infection among the pools of macerated Lu. longipalpis females; when taking into account the number of individual specimens tested, we determined an infection rate of at least $0.47 \%$ ( 1 out of 28 pools, with at least 1 infected insect in the positive pool). Previous studies using various PCR-based techniques to determine region-specific $L u$. longipalpis infection rates in MS determined a rate of $0.25 \%$ in Bonito (Savani et al. 2009), whereas in the older settled foci in Campo

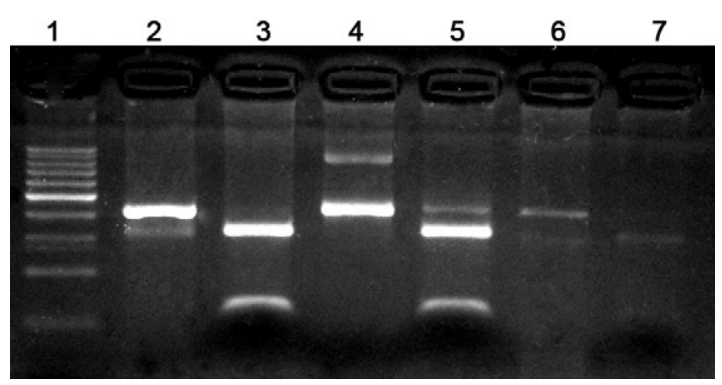

Polimerase chain reaction (PCR) amplification product of Leishmania infantum and the restriction fragment length polymorfism pattern obtained with Eae I. Lane 1: MW 100 bp DNA ladder; 2: PCR product from canine lymph node sample (uncut); 3: digested PCR product; 4: PCR product from canine lymph node sample (uncut); 5 : digested PCR product; 6: PCR product from phlebotomine sample; 7: digested PCR product. 
Grande and Corumbá, it reached $1.9 \%$ for Leishmania spp (Silva et al. 2008) and 1.5\% for the Lu. longipalpis sibling species (and proven vector of L. infantum) Lutzomyia cruzi (de Pita-Pereira et al. 2008), respectively. Aside from differences in the sampling strategies and techniques used, the differences could be related to the eco-epidemiology of each urban VL foci. The spatial distribution of $L u$. longipalpis in Posadas resembled a clustered pattern (Fernández et al. 2010); the infection and transmission rates could be higher in these "patches" of vector abundance.

One of the five vector incrimination criteria suggested by Killick-Kendrick (1990) is the simultaneous identification of Leishmania genus in patients and sand flies in a given area. This requires parasite visualization in both the vector digestive tract and mammalian samples, which would typically be followed by culture isolation and other time-consuming laboratory techniques (Aransay et al. 2000, Santamaría et al. 2005). Although these techniques are considered the gold standards, in the last two decades the development of PCR and other molecular biology assays have made testing in less-advanced laboratories practical and have enabled the use of highly sensitive diagnostic tools in areas where such diseases strongly impact the population. In particular, the usefulness of these techniques with respect to leishmaniasis lies in their ability to quickly identify Leishmania species, allowing for better surveillance of the vector directly involved in the transmission cycle (Cruz et al. 2006, Moreira et al. 2007, de Pita-Pereira et al. 2008).

\section{DISCUSSION}

In conclusion, though parasite DNA detection is an indirect method of isolation (Alvar Ezquerra 2001) that does not distinguish between the presence and viability of parasites, sequence-based species confirmations were consistent with previous immunoserological results using samples from humans and dogs in the same geographic area (Salomon et al. 2008). Therefore, for the first time in Argentina, the local genotypification of $L$. infantum by RFLP-PCR, together with the direct observation of amastigote forms in lymph node smears, implicated dogs as reservoirs and Lu. longipalpis as potential vectors in this urban focus.

This scenario is similar to those described in recently developed foci that formed during the dispersion of VL to the southern cities of South America through Brazil (Silva et al. 2008) and Paraguay (Cousiño 2006) prior to reaching this southernmost focus in Argentina. The similarities between these foci validate the importance of designing regional control strategies. Likewise, the clustered distribution of sand flies observed in Posadas (Fernández et al. 2010) and the infection rates presented in this report highlight the need for research on parasite circulation in these spatially heterogeneous urban scenarios to improve the current control approaches.

Furthermore, the proper identification of parasite species through highly sensitive and specific alternative techniques such as RFLP-PCR is of epidemiological and clinical importance. This is particularly true in areas where Leishmania amazonensis could be present, such as Argentina (Frank et al. 2003), as well as MS (Lima Junior et al. 2009), where it could be infecting Lu. longipalpis (Savani et al. 2009), a species that is also capable of transmitting VL (Almeida et al. 1996, Aleixo et al. 2006, Tolezano et al. 2007).

\section{ACKNOWLEDGEMENTS}

To Dr Lilian Tartaglino (Secretaria Calidad de Vida) and the technicians of the Entomology Laboratory of the Municipality of Posadas, for providing local support during the sampling.

\section{REFERENCES}

Aleixo JA, Nascimento ET, Monteiro GR, Fernandes MZ, Ramos AM, Wilson ME, Pearson RD, Jeronimo SM 2006. Atypical American visceral leishmaniasis caused by disseminated Leishmania amazonensis infection presenting with hepatitis and adenopathy. Trans R Soc Trop Med Hyg 100: 79-82.

Almeida RP, Barral-Netto M, De Jesus AM, De Freitas LA, Carvalho EM, Barral A 1996. Biological behavior of Leishmania amazonensis isolated from humans with cutaneous, mucosal or visceral leishmaniasis in BALB/C mice. Am J Trop Med Hyg 54: 178-184.

Alvar Ezquerra JP 2001. Diagnostico. In JP Alvar Ezquerra, Las leishmaniasis: de la biologia al control, 2nd ed., Laboratorios Intervet, Salamanca, p. 103-111.

Andrade Filho JD, Galati EAB, Falcão AL 2003. Redescription of $N y$ ssomyia intermedia (Lutz \& Neiva, 1912) and Nyssomyia neivai (Pinto, 1926) (Diptera: Psychodidae). Mem Inst Oswaldo Cruz 98: 1059-1065.

Aransay AM, Scoulica E, Tselentis Y 2000. Detection and identification of Leishmania DNA within naturally infected sand flies by seminested PCR on minicircle kinetoplastic DNA. Appl Environ Microbiol 66: 1933-1938.

Cousiño B 2006. Vigilancia y Control de la Leishmaniasis en el Paraguay. In Panaftosa, Informe Final de la Reunión de Expertos OPS/OMS sobre Leishmaniasis Visceral en lãs Américas, OPS, Rio de Janeiro, p. 34-36.

Cruz I, Chicharro C, Nieto J, Bailo B, Cañavate C, Figueras MC, Alvar J 2006. Comparison of new diagnostic tool of management of pediatric Mediterranean visceral leishmaniasis. J Clin Microbiol 44: 2343-2347.

de Pita-Pereira D, Alves CR, Souza MB, Brazil RP, Bertho AL, de Figueiredo Barbosa A, Britto CC 2005. Identification of naturally infected Lutzomyia intermedia and Lutzomyia migonei with Leishmania (Viannia) braziliensis in Rio de Janeiro (Brazil) revealed by a PCR multiplex non-isotopic hybridisation assay. Trans R Soc Trop Med Hyg 99: 905-913.

de Pita-Pereira D, Cardoso MA, Alves CR, Brazil RP, Britto C 2008. Detection of natural infection in Lutzomyia cruzi and Lutzomyia forattinii (Diptera: Psychodidae: Phlebotominae) by Leishmania infantum chagasi in an endemic area of visceral leishmaniasis in Brazil using PCR multiplex assay. Acta Trop 107: 66-69.

Fernández MS, Salomón OD, Cavia R, Perez AA, Acardi SA, Guccione JD 2010. Lutzomyia longipalpis spatial distribution and association with enviromental variables in an urban focus of visceral leishmaniasis, Misiones, Argentina. Acta Trop 114: 81-87.

Frank FM, Fernández MM, Taranto NJ, Cajal SP, Margni RA, Castro E, Thomaz-Soccol V, Malchiodi EL 2003. Characterization of human infection by Leishmania spp in the Northwest of Argentina: immune response, double infection with Trypanosoma cruzi and species of Leishmania involved. Parasitology 126: 31-39.

Gontijo B, de Carvalho M de L 2003. American cutaneous leishmaniasis. Rev Soc Bras Med Trop 36: 71-80. 
Jorquera A, González R, Marchán-Marcano E, Oviedo M, Matos M 2005. Multiplex-PCR for detection of natural Leishmania infection in Lutzomyia spp captured in an endemic region for cutaneous leishmaniasis in state of Sucre, Venezuela. Mem Inst Oswaldo Cruz 100: 43-46.

Killick-Kendrick R 1990. Phlebotomine vector of leishmaniases: a review. Med Vet Entomol 4: 1-24.

Lima Junior MS, Andreotti R, Dorval ME, Oshiro ET, Oliveira AG, Matos M de F 2009. Identificação de espécies de Leishmania isoladas de casos humanos em Mato Grosso do Sul por meio da reação em cadeia da polimerase. Rev Soc Bras Med Trop 42: 303-308.

Marfurt J, Niederwieser I, Makia ND, Beck HP, Felger I 2003. Diagnostic genotyping of Old and New World Leishmania species by PCR-RFLP. Diagn Microbiol Infect Dis 46: 115-124.

Moreira MA, Luvizotto MC, Garcia JF, Corbett CE, Laurenti MD 2007. Comparison of parasitological, immunological and molecular methods for the diagnosis of leishmaniasis in dogs with different clinical signs. Vet Parasitol 145: 245-252.

Myler PJ, Stuart KD 2000. Recent developments from the Leishmania genome project. Curr Opin Microbiol 3: 412-416.

PAHO - Pan American Health Organization 2008. Update of American trypanosomiasis and leishmaniasis control and reserch: final report, PAHO/HDM/CD/512-2008, PAHO, Rio de Janeiro, 176 pp.

Salomon OD, Sinagra A, Nevot MC, Barberian G, Paulin P, Estevez
JO, Riarte A, Estevez J 2008. First visceral leishmaniasis focus in Argentina. Mem Inst Oswaldo Cruz 103: 109-111.

Salomon OD, Sosa Estani S, Rossi GC, Spinelli GR 2001. Presencia de Lutzomyia longipalpis y situación de la leishmaniasis visceral en Argentina. Medicina (B Aires) 61: 174-178.

Santamaría E, Ponce N, Puerta C, Ferro C 2005. Validation of PCR as tool for the detection of Leishmania (Viannia) spp parasites in the Lutzomyia (Diptera: Psychodidae) vector. Biomedica 25: 271-279.

Savani ES, Nunes VL, Galati EA, Castilho TM, Zampieri RA, Floeter-Winter LM 2009. The finding of Lutzomyia almerioi and Lutzomyia longipalpis naturally infected by Leishmania spp in a cutaneous and canine visceral leishmaniases focus in Serra da Bodoquena, Brazil. Vet Parasitol 160: 18-24.

Silva EA, Andreotti R, Dias ES, Barros JC, Brazuna JC 2008. Detection of Leishmania DNA in phlebotomines captured in Campo Grande, Mato Grosso do Sul, Brazil. Exp Parasitol 119: 343-348.

Tolezano JE, Uliana SR, Taniguchi HH, Araújo MF, Barbosa JA, Barbosa JE, Floeter-Winter LM, Shaw JJ 2007. The first records of Leishmania (Leishmania) amazonensis in dogs (Canis familiaris) diagnosed clinically as having canine visceral leishmaniasis from Araçatuba County, São Paulo state, Brazil. Vet Parasitol 149: 280-284.

Young DG, Duncan MA 1994. Guide to the identification and geographic distribution of Lutzomyia sand flies in Mexico, the West Indies, Central and South America (Diptera: Psychodidae). Mem Am Entomol Inst 54: 1-881. 